\title{
5
}

\section{The Consequences of Disaggregation and the Impossibility of a Third Way}

\author{
Ronan McCrea
}

Disaggregating religion as Laborde (forthcoming) has done is a highly informative exercise. Analysing the various components of what we call 'religion' separately, and looking at the different issues raised by how each component interacts with the liberal state, allows us to see what is and what is not problematic about departures from the principle of separation of religion and state.

Interestingly, the disaggregation process reveals that there are many forms of religion that lack some of the features that tend to render state endorsement problematic. Furthermore, disaggregation shows that there are non-religious forms of identity and belief that can pose similar problems to those posed by religion in its interaction with the liberal state. In the light of this information, one might well think that it is wrong to single out religion by requiring the state to adhere to religious neutrality. This chapter argues that notwithstanding these important insights from the disaggregation process, requiring states to maintain religious neutrality by neither symbolically endorsing any faith nor allowing religious norms to provide the basis for law is the best option in the contemporary West.

My argument is as follows. States may endorse religion (i.e. depart from the principle of religious neutrality) in two potentially problematic ways. One is to allow religious norms to act as the basis for law and policy. The other is to endorse a particular faith symbolically (for example by placing the symbols of a particular faith in state institutions). I assume here that the religious nature of the symbol is clear. There may be circumstances where the cultural influence of a particular faith means that it is unclear whether a particular symbol (such as the cross on Scandinavian flags) has achieved a post-religious meaning, but that is an issue which I will not, for reasons of space, be addressing. 
I will argue that permitting state institutions to symbolically endorse a particular faith or allowing religious arguments to form the basis of law both involve the state using its powers and institutions to promote particular faiths. This raises the risk that religions will compete for control of state institutions in order to access this promotional power. This is likely to produce political conflict that is more likely to be intractable than conflict on other bases, because of the problematic features of religion highlighted by Laborde in her disaggregation of religion.

The fact that, in respect of each individual problematic feature so identified, there exist non-religious equivalents demonstrating the same feature and that some religions may lack a particular problematic feature, does not undermine the case for singling out religion by requiring the state to be religiously neutral. This is because predominant religions in the West combine these problematic factors in a way in which religious analogues generally do not.

Of course, religion is a diverse phenomenon and not all forms of religion embody the problematic features that disaggregation shows to be behind the impulse to impose a duty of religious neutrality on the state. Indeed, secularism, as is well known, is, historically and currently, structured around the political problems posed by particular forms of religion (Lilla 2007). Nevertheless, the only way of dealing with the political problem posed by predominant forms of religion in the West, both then and now, involves an overinclusive approach to all religions, including those that may lack the problematic features of the form of religion that inspired the separation of religion and law in the first place. This is because the effectiveness of the secular solution to the religious problem requires a degree of cognitive dissonance on the part of missionary religions such as Christianity and Islam that can only function if the criterion for exclusion relates to religion in the abstract rather than particular religious beliefs. Without such a category distinction, it will be impossible for believers to political actions that may be inconsistent with their missionary faith while retaining a religious identity that may be valuable to them.

\subsection{THE PROBLEM}

Laborde's work (forthcoming) identifies four features of religion that are in tension with key features of the liberal democratic state.

- Religious reasons can be inaccessible to non-believers in the faith in question and therefore religiously justified laws are in tension with the idea that law should be formed by deliberation and discussion and should be supported by comprehensible reasons. 
- Religion is a form of almost immutable identity as well as a set of beliefs and practices. Thus, association between the state and a particular faith is exclusionary in the same way that association between the state and a particular racial identity would be exclusionary.

- Religions can be comprehensive in that they often deal with all areas of life, including private life and accordingly religiously influenced law risks clashing with the liberal commitment to protection of privacy and individual autonomy.

- Finally, granting political authority to religion is inconsistent with democratic ideas of collective self-government as a politically sovereign deity is a rival to the sovereignty of the people in a democratic system.

What is interesting about these reasons is that there are clear examples of religions which do not share a particular problematic feature and there are non-religious beliefs that do. Some religious reasons may be quite easy to understand for non-believers (even if their binding quality on believer is not). After all, even controversial religious teachings on abortion or divorce, for example, have relatively obvious non-religious reasons to support them. There are also religions that believe in personal autonomy or which lack the idea of a human-like God with concrete intentions about how life ought to be lived on earth. Equally, some secular belief systems may be comprehensive and many dispute the idea that non-religious moral beliefs can be distinguished on rational grounds from religious beliefs (Marshall 1993).

Disaggregating religion provides helpful clarity on what elements of religion can be problematic. However, religion does not exist in the world in disaggregated form and my contention is that it is the combination of the factors identified by Laborde that make it necessary to separate religion from the state. There are viewpoints that are not fully rational or accessible, those that are identity-related, those that are comprehensive, and those that are inconsistent with popular sovereignty, but it is difficult to think of non-religious viewpoints that combine these factors in the way that most forms of Christianity and Islam (the predominant forms of religion in the modern West) do.

\subsection{COMBINATION EFFECT: RELIGION AS A PARTICULARLY DISRUPTIVE PHENOMENON}

All political decisions involve some degree of alienation on the part of the minority but because religion is often felt to be part of personal identity and is rarely readily mutable, exclusion on religious grounds is liable to be particularly destabilizing politically. This is not just because religious identity is so 
keenly felt, though that is the case, it is also because its relative immutability means that political polarization on religious lines is likely to produce permanent political majorities that do not change over time and, as Lijphart has noted (1999), a key element of the stability of democratic systems is periodic changes in the political complexion of the majority party.

In addition, the comprehensive nature of religion means that religious laws risk curtailing the area of life not regulated by law to a large degree, further undermining the incentives for political minorities to accept the legislative verdicts of a religious majority. Again, we see that it is the combination of two factors (unchanging identity and comprehensive scope) that produces the greater threat of instability. Indeed, while Laborde's focus is on religion and the liberal state, the combination of the four potentially problematic features that she identifies provides the basis for non-liberal states and those who believe in at least some non-liberal forms of religion to endorse separation.

Note that here we are talking about a factual assessment of the impact of predominant forms of religion, not all religion. The key issue is not therefore whether religion always causes instability (it does not) or whether it is the sole cause of particular conflicts (conflicts rarely have a single explanation), but whether it is particularly likely to provide conflict. Critics of secularism, such as Armstrong (2014a), are guilty of setting up 'straw men' in this regard. Writing in relation to the European Wars of Religion, she states that 'while there is no doubt that the participants certainly experienced [these] wars as a life-and-death religious struggle, this was also a conflict between two sets of state-builders' (2014b). We can see that this critique does not really address the key issue which is whether the fact that these wars were religious made them more difficult to bring to an end (and whether they were more likely to break out because of religious contestation for political power in the post-Reformation period). Armstrong herself notes that 'the participants certainly experienced [the Wars of Religion] as a lifeand-death religious struggle' (2014b), something which must surely have tended to inflame the conflict and to make it more difficult to bring to a close through compromise.

This does not mean that always and everywhere, religion and only religion tends to produce political chaos and violence. Secularism grew up in relation to a particular crisis within Western Christianity in the fifteenth and sixteenth centuries. One should certainly bear the specificity of this history in mind when considering the usefulness of secularism in different times and places (as well as the impact that histories such as colonialism may have on how it is perceived). Certainly, not all religions pose the same threats of political chaos and violence. Societies where individuals' religious identity often changes over their life or whose dominant religious traditions either do not see God as having concrete views as to how life ought to be lived or preach cooperation and liberalism may have a low likelihood of religiously motivated political 
conflict. Such societies may not need to develop an intellectual art of separation'.

It is also true that religion is not the only phenomenon that is capable of being sufficiently disruptive to require that the state adopt a rigorously neutral attitude in relation to cleavages that relate to it. It is notable that the Belgian state has adopted what looks very like a 'linguistically secular' regime in relation to language. Indeed it is notable how disputes over symbolic linguistic arrangements in Belgium are remarkably similar to those over religious symbols in state contexts elsewhere. They often relate to a perceived symbolic harm of apparent favouring of one language. For example a policy where all federal signs were in both languages but where French was always twice the size of Dutch would not affect the right of Dutch speakers to access government services but would be incompatible with the symbolic equality needed to hold the loyalty of Dutch speakers to the Belgian state (for an argument on why secularism cannot be defended on the basis of rights claims see McCrea 2016). The aim of Belgian language policy is to cultivate a linguistically neutral federal state thus avoiding linguistically motivated contestation for political power that would produce intractable political conflict.

Therefore, a successful defence of separation of religion and state cannot be on the basis that all religion always causes conflict in a way that no other cleavage can. Rather, the argument is that predominant forms of religion in the modern West have characteristics that make them particularly likely to produce conflict and therefore religion ought to be kept separate from politics.

\subsection{WHY ALL RELIGION?}

If only some forms of religion are problematic, why then exclude all religion? If only particular types of religion, with particular characteristics, pose problems, is a system that excludes particular arguments on the basis that they belong to a category called 'religion' not guilty of practising an overinclusive form of exclusion?

This overinclusiveness is necessary. Even peace-loving, egalitarian religions must have their ability to shape law and politics restricted. The reason for this lies in Karen Armstrong's observation that during the Wars of Religion in Europe participants 'would not, and could not, have distinguished between religious and temporal factors in these conflicts' because 'There was as yet no coherent way to divide religious causes from social causes' (2104b). The problems caused by Christianity's relationship to politics seen in the Wars of Religion required the creation of a category of religion. This construction was not merely an artifice. It arose from the need for an intellectual category needed to reflect something real. Although the boundaries of religion, like any 
complex social institution, are fuzzy, this does not mean it does not exist. There was something about political disputes around the intentions of a divine being and which related to questions of eternal life and the nature of the universe that made them harder to solve in a peaceful way than disputes that related only to earthly matters. Thus, it is perhaps better to speak of the wars of religion as having facilitated the creation of an intellectual category that allowed us describe the phenomenon of religion rather than having created it (in the same way as the nineteenth-century creation of the concept of homosexuality as a form of identity involved the creation of an intellectual category to describe something that had existed but which had not been seen in those terms before). The elements of religion identified in Laborde's disaggregating process operate in two ways. They describe both what we now know as religion as well as indicating the kind of problems caused in political life that made it necessary to develop a category to describe those causes.

Once this category was created, its utility in political terms depended on it being applied to all forms of belief that fell within its boundaries. To seek to tailor separationist principles to allow 'good' religions to influence politics but to exclude 'bad' religions involves treating religion like all other forms of political difference. Such an approach defeats the aim of separation in the first place, namely the identification of religion as a special category in order to allow believers to square the circle and simultaneously hold eschatological or potentially conflict-encouraging religious views while endorsing cooperationprioritizing politics.

The art of separation was an attempt to allow believers to retain valued religious identities while neutralizing the eschatological politics that the predominant form of religion in Europe at the time (Christianity) reinforced and thereby allowing peaceful sharing of political institutions by a religiously divided population. Later on, a further incentive to accept such political limitations emerged in the form of guarantees of religious freedom and private autonomy which allowed significant scope for individuals to continue to live lives in accordance with their religious beliefs notwithstanding the fact that religions had been deprived of political power, but these liberal guarantees came well after the initial process of separating religion from politics.

The 'art of separation' attempted to short-circuit the process by which Christian theology would make its way into political life by avoiding looking at the content of religious beliefs and focusing instead on the role of religion in general in society. This system allows a politician such as US presidential candidate John Kerry to say that, as a Catholic, he accepts the Church's teaching that life begins at conception but that 'What is an article of faith for me is not something that I can legislate on somebody who doesn't share that article of faith' (Third BushKerry Debate 2004). After centuries of experiencing separation many Westerners can fail to see how remarkable it is to consider something to be religiously and morally true but inapplicable within the political realm. 
This approach relies on deliberately avoiding looking at the content of the actual religious belief when deciding on its acceptability in the political arena and instead on identifying its unusable nature in the fact that it belongs to the category of religious belief. Once the exclusionary criterion used relates to the particular beliefs or characteristics of a particular faith, rather than to the category of religion generally (i.e. once we try to exclude only problematic religious beliefs from acting as the basis of law) then believers are deprived of a mechanism that allows them to take actions inconsistent with that belief in the political arena by citing the category distinction between the religious and the political. A person holding illiberal beliefs can reject a law enforcing such beliefs without abandoning their religious identity if the reason for the rejection of the law is that religious beliefs as a general category cannot function as the basis for law. Once there is no absolute category exclusion of religion the same person can only reject such a law by rejecting their religious belief or making it subordinate to another substantive belief such as free choice (an action which may also involve painful rejection of a valued religious identity).

Thus, disaggregation is a useful tool for informing us as to what are the characteristics of religion that are particularly damaging to political coexistence but it would be a mistake to move from that to seeking to exclude only those forms of religion that possess such characteristics from public life. The efficacy of the mechanism chosen to remedy those damaging effects depends on an exclusion of all religion from political life by means of the category distinction that is fatally undermined if it is only applied to certain faiths.

Just as seeking to narrow down the forms of religion which are caught by exclusionary secular principles is unworkable, similarly attempts to narrow the sphere of applicability of these principles to the institutional sphere are unworkable. Arguments by Habermas (2003) and Bardon (2015) that the commitment to non-religious politics can be restricted to the institutional sphere cannot be reconciled with the inevitable link between the electorate and broader public debate on political matters on the one hand and elected officials on the other. The idea that elections and political debate could be conducted along religious lines but that elected officials would not then rely on religious arguments when exercising power assumes an unrealistic separation between elected officials and electoral politics (as well as excluding occasions such as referendums when voters exercise direct power). A sustainable political system cannot be run on the basis that leaders campaign promising to follow Marx but then govern like Hayek.

\subsection{THE INEVITABILITY OF SIDE EFFECTS}

Secular principles are in some way like chemotherapy. Killing cancer cells is not currently possible without also killing other healthy cells and, indeed, imposing burdens on the patient. Science may come up with smart cancer 
therapies that target only cancer cells and which do not have the side effects of chemotherapy. However, there cannot be a 'secular smart therapy'. The curative mechanism of secularism depends on excluding all religion in order to enable believers to take political actions that may be inconsistent with those beliefs without sacrificing their religious identity.

The costs involved are not trivial. As secular principles are in tension with predominant interpretations of Islam as practised in many of the countries from which many migrants to Europe originate, migrants, who already struggle with socioeconomic exclusion, can experience secular norms as a further source of exclusion. There is also a loss of the richness that political beliefs bring to life from public debate. The temptation to try to harness positive elements of religious theology in order to achieve laudable political aims will always be present. Many religions have laudable beliefs that could aid the realization of worthy goals. For example, both Christian and Islamic theologians have argued that religion gives mankind a duty to take care of the environment. Rousseau felt that a secularized politics would impoverish mankind as, 'by failing to account for what was best or highest in human beings, it would encourage what was lowest in them' (Lilla 2007). The observations of Buruma and Margalit (2004) in relation to critics of liberal capitalism could equally apply to the notion of secular politics. They note that 'The anti-heroic nature of Western liberalism is the greatest enemy of religious radicals, priest-kings and collective seekers after purity and heroic salvation' and that 'the bourgeois, often philistine, un-heroic, anti-utopian nature of liberal civilization can make it difficult to defend'.

Secular politics is less inspiring than a politics that seeks to use collective institutions to answer fundamental questions. It may even make it more difficult to win majority support for vital goals, such as environmental protection, that require self-sacrifice in the interest of others. Many who want to move to a 'post-secular' era are well motivated and are seeking to harness the passions of religious belief in order to achieve worthy goals. However, in doing so they undermine the category distinction that provides the mechanism that can shield political cooperation and liberal laws from potentially conflictcausing and illiberal beliefs while at the same time allowing as many of those as possible who hold those beliefs to retain their religious identity. Once this undermining has occurred we risk being left with no means to protect our political structures when the same passions threaten to provoke passionate religious conflict for political power. How can one claim that Islamic teaching is a sufficient basis for a law prohibiting pollution and then turn around and say the law cannot enforce religious teaching when met with religious arguments for the criminalization of homosexuality? Does this approach not involve a greater risk of forcing a choice between religious identity and liberal values or consensual politics than a category distinction that allows the possibility of holding to a religious truth without it being applicable within 
the political arena? The choice made in the West as Lilla rightly concludes is one that is 'difficult' and which 'demands self-awareness'. It is a choice to have less exciting, passionate, and spiritually uplifting politics to 'limit our politics to protecting individuals from the worst harms they can inflict on one another... while leaving their spiritual destinies in their own hands' (Lilla 2007).

We cannot have a politics that has both the upside of religious passion without the downside of religious conflict for political power. There is no doubt that there is an element of loss. Martin Luther King's plea for racial equality was enriched by religious elements that cannot be fully captured by arguments that meet the secular standards of public reason. People will feel frustration at the degree of separation of their religious identity from their political actions. When people have to 'translate' their religious feelings into secular language some richness may be lost. This does not mean they are being dishonest. When one argues for a law one is meant to put forward reasons that one regards as sufficient to justify enacting the law, not to give an emotional history of one's beliefs. Although some have argued against the requirement of public reason on grounds that it provokes dishonesty in public life, there is no deception when an individual with a religious commitment which makes her hostile to divorce challenges herself as to whether she can find non-religious reasons to offer her fellow citizens for a law banning divorce before speaking in favour of such a law. She is not denying her true reasons but merely acknowledging that religious impulses must be reformulated because of the need for political cooperation in a religiously diverse society.

\subsection{DEFINITION}

Having such an overinclusive definition of religion inevitably raises the issue of the definition of religion. In the West, the definition for the purposes of state neutrality is for historical reasons structured around the Western Christian form of religion whose problematic relationship to the political sphere (in the context of religious diversity) prompted the development of secular politics in the first place. Any definition will have as its central case a human-like deity who is seen as having intentions about how life ought to be organized on earth perhaps with such views being reflected in an authoritative text. As with all definitions, there will be marginal cases but the more a belief system resembles this central case, in particular if it refers to non-human sources of authority, relies on faith rather than purely rational grounds, the more likely it will be that it will be seen as falling within the definition. Some religious traditions will lack some of these characteristics (e.g. Buddhism) but 
will fulfil enough of the criteria to be seen as religions for the purposes of this test. Other faiths may have the problematic characteristics to a degree even greater than Christianity.

Even though strong humanist elements within Christianity have made it easier for many Christian denominations than some other faiths to accept, even if only as a matter of realpolitik, the idea of a secular political order, there are still unavoidable tensions for Christian believers. For adherents to some other faiths, such tensions may be even greater. The greater the degree to which believers see God as having laid down law-like rules, the harder it will be for them to accept the legitimacy of man-made legal rules that appear to go against such divine law. The vast majority of Muslims regard the Koran as partly a legal text and also the unadulterated word of God (Ruthven 2012). Most adherents to ultra-Orthodox Judaism also see their holy text as a legal document to a significant extent. Such an approach to a holy text will often make it harder for believers to adapt to a secular political order. Approaches to a holy text that see it as a human rendition of God's beliefs and desires will have greater scope to disregard a part of the text that appears contrary to secular law or liberal norms as potentially erroneous (on the basis that human imperfection means that the relevant part of the holy text is an incorrect reflection of God's will) or as subject to revaluation in the light of modern norms and knowledge. This allows greater scope for avoiding a direct clash between the authority of divine and human lawmakers. That is not to say that Islam is necessarily incompatible with a secular state. Textual religious traditions always involve interpretation and diverse views of the will of the divine. However, it is true that certain predominant approaches to the text (such as seeing it as divinely authored rather than humanly authored with divine inspiration) can pose greater difficulties for believers in accepting the legitimacy of the secular state.

\subsection{CONCLUSION}

Separating religion and politics is not cost free but is better than the alternative. The idea of identifying religious arguments as a category of argument that is inapplicable within the political arena was and remains a reaction to a factual assessment of the likelihood that religiously motivated politics would cause intractable conflict and may render political cooperation impossible. This is a factual assessment in relation to prominent forms of religion that is either true or false. Recent history in places like Iraq and Syria add strength to this factual assessment. Conflicts in these areas have many factors but achieving compromise is certainly not helped by the religious character of political divisions in these countries. 
Predominant forms of religion in the modern West do have many of the problematic factors identified in the disaggregation of religion and they combine to make religiously motivated politics highly likely to produce instability and conflict. Although not all forms of religion share these characteristics it is not possible to seek to exclude only problematic religion from political life. Doing so undermines the category distinction that allows space for believers to retain their religious identity while making political compromises potentially inconsistent with their religious beliefs. Without this category distinction such cognitive dissonance is not possible.

For some, even this category distinction will not lessen the religious burden of cooperation. For some, the imperative of ensuring God's rule on earth comes above all other considerations. For them, an absence of political cooperation and continual violence are a price worth paying for the chance to establish religious virtue on earth. There is no compromise possible with those who hold this view. If one insists on phrasing one's arguments in the political arena in terms that assert that one's own religion is correct and all others should be forced follow it, one is rejecting the idea of political cooperation between faiths and one should not be accommodated. The aim of secularism is to co-opt the maximum number of people who have some commitment to the cause of political coexistence. The cognitive-dissonance-promoting category distinction behind the idea of public reason is the most effective way of minimizing the number of those who cannot be enticed into political cooperation by providing a mechanism to allow valued religious identities to coexist with political actions that may be inconsistent with religious teachings.

Disaggregating is enormously informative in that it identifies elements of religion that are more and less problematic in political terms. But disaggregation is not a reason to abandon or lessen the restrictions on religious involvement in political life because religion does not operate in a disaggregated fashion in the world. The combination of the factors identified in the disaggregation process means that the conflict-causing capacity of religion taken as a whole is greater than the sum of the conflict-causing capacity of each of its disaggregated elements. Therefore, while disaggregation is a useful exercise, it ends up reinforcing a blanket exclusion of religion from political life.

\section{REFERENCES}

Armstrong, K., 2014a. Fields of Blood: Religion and the History of Violence. Bodley Head.

Armstrong, K., 2014b. The Myth of Religious Violence. Guardian, 25 September 2014. Available online: <http://www.theguardian.com/world/2014/sep/25/-sp-karenarmstrong-religious-violence-myth-secular>. 
Bardon, A., 2015. Religious Arguments and Public Justification. In: J.L. Cohen and C. Laborde, eds, Religion, Secularism and Constitutional Democracy. Columbia University Press.

Buruma, I. and Margalit, A., 2004. Occidentalism: The West in the Eyes of Its Enemies. Penguin.

Habermas, J., 2003. Intolerance and Discrimination. International Journal of Constitutional Law 1: 2.

Laborde, C., forthcoming. Liberalism's Religion. Harvard University Press.

Lijphart, A., 1999. Patterns of Democracy. Yale University Press.

Lilla, M., 2007. The Stillborn God: Religion, Politics and the Modern West. Knopf/ Random House.

Marshall, W., 1993. The Other Side of Religion. Hastings Law Journal 44: 843.

McCrea, R., 2016. Rights, Recourse to the Courts and the Relationship between Religion, Law and State in Europe and the United States. EUI working paper, Robert Schuman Centre for Advanced Studies, RSCAS 2016/09, European University Institute.

Ruthven, M., 2012. Islam: A Very Short Introduction. Oxford University Press.

Third Bush-Kerry Debate, Tempe Arizona, 13 October 2004. Available online: $<\mathrm{http}$ //www.ontheissues.org/social/John_Kerry_Abortion.htm>. 